Maria Antonietta Grignani (a cura di), Francia e Algeria: passato, presente e futuro di un dialogo fra culture. Atti del convegno internazionale (Siena, $10,11,12$ novembre 2003)

\title{
Veronica Amadessi
}

\section{(2) OpenEdition}

\section{Journals}

Edizione digitale

URL: https://journals.openedition.org/studifrancesi/26921

DOI: $10.4000 /$ studifrancesi. 26921

ISSN: 2421-5856

\section{Editore \\ Rosenberg \& Sellier}

\section{Edizione cartacea}

Data di pubblicazione: 1 avril 2007

Paginazione: 221

ISSN: 0039-2944

\section{Notizia bibliografica digitale}

Veronica Amadessi, «Maria Antonietta Grignani (a cura di), Francia e Algeria: passato, presente e futuro di un dialogo fra culture. Atti del convegno internazionale (Siena, 10,11,12 novembre 2003)», Studi Francesi [Online], 151 (LI | I) | 2007, online dal 30 novembre 2015, consultato il 22 novembre 2021. URL: http://journals.openedition.org/studifrancesi/26921 ; DOI: https://doi.org/10.4000/studifrancesi. 26921

Questo documento è stato generato automaticamente il 22 novembre 2021.

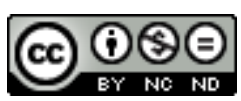

Studi Francesi è distribuita con Licenza Creative Commons Attribuzione - Non commerciale - Non opere derivate 4.0 Internazionale. 


\title{
Maria Antonietta Grignani (a cura di), Francia e Algeria: passato, presente e futuro di un dialogo fra culture. Atti del convegno internazionale (Siena, 10,11,12 novembre 2003)
}

\author{
Veronica Amadessi
}

\section{NOTIZIA}

MARIA ANTONIETTA GRIGNANI (a cura di), Francia e Algeria: passato, presente e futuro di un dialogo fra culture. Atti del convegno internazionale (Siena, 10,11,12 novembre 2003), Pisa, Pacini, 2006, pp. 78.

1 L'Università per stranieri di Siena propone un'interessante riflessione a più voci sulla relazione tra Francia e Algeria, ripercorrendo la storia comune dei due paesi e dando spazio ad interventi di carattere sociologico, linguistico e letterario. Il volume riunisce le cinque comunicazioni presentate in occasione del convegno, più la presentazione del curatore, e un dvd su cui è stato masterizzato il concerto che si tenne per l'occasione. Dopo una sommaria cronologia dall'inizio dell'Ottocento agli anni Sessanta del Novecento, troviamo un omaggio a Jacques Berque, grande islamista, traduttore del Corano, professore e amministratore coloniale. Berque rifletté a lungo sulla colonizzazione e sul dialogo fra culture, affermando che "la colonisation n'est pas seulement une exploitation du sol et des êtres. Elle est surtout, et d'abord, rupture de sens dans les signes et les choses. La colonisation consiste à obliger un peuple à se désadhérer de ses bases" (p. 22). Seguono uno studio sugli usi sociali di internet in Algeria, e due articoli sulla questione della lingua: il primo, di Abdel Malek Smari, tratta dello status della lingua francese nel Maghreb e del problema dell'identità legato a 
questioni anche letterarie (il legame lingua-scrittura, ad esempio). Il secondo di Brunella Eruli è invece dedicato ad Assia Djebar e alla delicata questione della lingua nelle sue opere. Partendo da estratti di alcuni saggi critici e dai romanzi dell'autrice maghrebina, Eruli fa notare che la lingua non è solo formalità o apparenza in Assia Djebar, bensì una dimensione che ricopre anche la vita politica, sociale, affettiva, la vita tout court; l'uso del francese diventa quindi una scelta ed equivale a prendere posizione nei confronti della propria storia. La lingua dell'ex-colonizzatore si trasforma in un "bottino di guerra", viene per così dire saccheggiata, senza però rompere con la cultura d'origine. Sono molti i riferimenti al saggio di Assia Djebar Ces voix qui m'assiègent: en marge de ma francophonie, dove si coglie tutta l'ambiguità sottesa alla definizione di "autore francofono". La relazione si chiude con un commento dell'ultimo romanzo della scrittrice algerina.

2 Gli atti del convegno di Siena rappresentano un'utile occasione per approfondire il difficile rapporto tra due paesi, da un punto di vista storico, sociologico e letterario. 